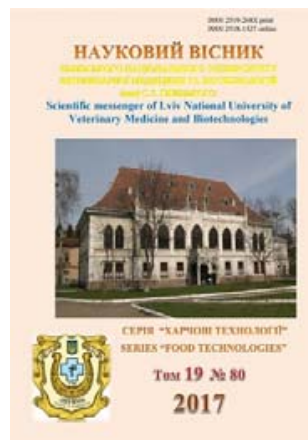

Науковий вісник Львівського національного університету ветеринарної медицини та біотехнологій імені С.3. Гжицького

Scientific Messenger of Lviv National University of Veterinary Medicine and Biotechnologies

doi:10.15421/nvlvet8003

ISSN 2519-268X print

ISSN $2518-1327$ online

http://nvlvet.com.ua/

УДК 637.127.576

\title{
Підбір умов для препаративного електрофорезу протеїнів сироватки молока у нативних умовах
}

\author{
В.Г. Юкало, К.Є. Дацишин \\ biotech@tu.edu.te.ua \\ Тернопільський національний технічний університет імені Івана Пулюя, \\ вул. Руська, 56, м. Тернопіль, 46001, Украӥна
}

\begin{abstract}
Протеїни сироватки молока є попередниками більще сотні біоактивних пептидів. Ці пептиди можуть утворюватися в процесі травлення у шлунково-кишковому тракті, а також за дї протеаз молочнокислих бактерій $і$ молокозгортальних препаратів. Серед них знайдено інгібітори ангіотензин-перетворювального ензиму, пептиди з опіоїдною та бактерицидною дією, імуномодуляторні та гіпохолестеролемічні пептиди, пептиди, які впливають на моторику кишечника, апетит та інші. Біоактивні пептиди з протеїнів сироватки молока становлять значний інтерес для створення функиіональних продуктів або продуктів з профілактичними властивостями. Створення таких продуктів передбачає виділення біоактивних пептидів певної біологічної дії. Враховуючи специфіку їх розміщення у первинній структурі доцільним є використання для їх отримання гомогенних протеїнів-попередників з сироватки молока. Одним з методів для одностадійного розділення протеїнів сироватки молока є диск-електрофорез в нативній системі ПААГ для лужних і нейтральних протеїнів. Метою даної роботи було встановити параметри препаративного варіанту диск-електрофорезу для виділення гомогенних протеїнів сироватки молока. Дослідження проводили на модифікованому апараті Стадієра. Протеїни сироватки молока виділяли осадженням казеїнів в ізоелектричній точиі. Осад казеїнів відділяли иентрифугуванням. Для ідентифікації протеїнів сироватки молока використовували гомогенні фракиії $\alpha$-лактальбуміну $(\alpha-L A)$ i $\beta$-лактоглобуліну $(\beta-L G)$, які отримували шияяом повторної гель-фільтрації на сефадексі G-100(fine). Гомогенність і фракиійний склад протеїнів сироватки молока визначали аналітичним диск-електрофорезом у пластинах поліакриламідного гелю. Конщентрацію протеїнів у зразках визначали спектрофотометрично (спектрофотометр СФ-46) при довжині хвилі $\lambda=280$ нм.

Отримані результати доводять доџільність використання пластинок ПААГ для препаративного фракціонування протеїнів сироватки молока. Встановлено допустиму тривалість і умови ідентифікації протеїнових фракцій. Показано, щзо вихід протеїнів у складі гомогенних фракцій становить 69,2\%. При ияьому співвідношення між кількістю отриманих фракизй ( $\beta$-LG, $\alpha-L A, B S A$ і IG) близьке до їх розподілу у сироватиі молока.
\end{abstract}

Ключові слова: протеїни сироватки молока, виділення протеїнових фракцій, препаративний електрофорез.

\section{Подбор условий для препаративного электрофореза протеинов сыворотки молока в нативных условиях}

\author{
В.Г. Юкало, К.С. Дацишин \\ biotech@tu.edu.te.ua
}

Тернопольский наџиональный технический университет имени Ивана Пулюя, ул. Русская, 56, г. Тернополь, 46001, Украина

\begin{abstract}
Протеины сыворотки молока являются предшественниками более сотни биоактивных пептидов. Эти пептиды могут образовываться в прочессе пищеварения в желудочно-кишечном тракте, а также под действием протеаз молочнокислых бактерий и молокосвертывающих препаратов. Среди них обнаружены ингибиторы ангиотензин-превращающего фермента, пептиды с опиоидным и бактерицидным действием, иммуномодулирующие и гипохолестеролемические пептиды, пептиды, которые влияют на моторику кичечника, аппетит и др. Биоактивные пептиды из протеинов сыворотки молока
\end{abstract}

Citation:

Yukalo, V.G., Datsyshyn, K.Ye. (2017). Selection of conditions for preparative electrophoresis of milk whey proteins in native conditions. Scientific Messenger LNUVMB, 19(80), 13-17. 
представляют значительный интерес для создания функииональных продуктов или продуктов с профилактическими свойствами. Создание таких продуктов предусматривает выделение биоактивных пептидов определенного биологического действия. Учитывая специфику их размещуения в первичной структуре, иелесообразным является использование для их получения гомогенных протеинов-предшественников из сыворотки молока. Одним из методов для одностадийного разделения белков сыворотки молока является диск-электрофорез в нативной системе ПААГ для щелочных и нейтральных протеинов. Целью данной работы было установить параметры препаративного варианта диск-электрофореза для вылеления гомогенных протеинов сыворотки молока. Исследования проводились на модифицированном аппарате Стадиера. Протеины сыворотки молока выделяли осаждением казеина в изоэлектрической точке. Осадок казеина отделяли иентрифугированием. Для идентификации протеинов сыворотки молока использовали гомогеннье фракции $\alpha$-лактальбумин ( $\alpha$-LА) и $\beta$ лактоглобулина ( $\beta$-LG), которые получали путем повторной гель-фильтрации на сефадексе G-100 (finе). Гомогенность и фракционный состав протеинов сыворотки молока определяли аналитическим диск-электрофорезом в пластинах полиакриламидного геля. Концентрацию протеинов в образцах определяли спектрофотометрически (спектрофотометр СФ-46) при длине волны $\lambda=280 \mathrm{нм.}$

Полученные результаты доказывают изелесообразность использования пластин ПААГ для препаративного фракционирования белков сыворотки молока. Установлено допустимую продолжительность и условия идентификации белковых фракций. Показано, что выход протеинов в составе гомогенных фракций составляет 69,2\%. При этом соотношение между количеством полученных фракций ( $\beta-L G, \alpha-L A, B S A$ и IG) близко к их распределению в сыворотке молока.

Ключевые слова: протеины сыворотки молока, выделения протеиновых фракций, препаративный электрофорез.

\title{
Selection of conditions for preparative electrophoresis of milk whey proteins in native conditions
}

\author{
V.G. Yukalo, K.Ye. Datsyshyn \\ biotech@tu.edu.te.ua \\ Ternopil National Technical University Ivan Pul'uj, \\ Ruska Str., 56, Ternopil, 46001, Ukraine
}

\begin{abstract}
Milk whey proteins are precursors of more than a hundred bioactive peptides. These peptides may be formed in the digestive process in the gastrointestinal tract, as well as under the influence of lactic acid bacteria proteases and milk-clotting preparations. Among them, inhibitors of angiotensin-converting enzyme, opioid and bactericidal peptides, immunomodulatory and hypocholesterolemic peptides, peptides that have an effect on intestinal motility, appetite, and others have been found. Bioactive peptides from whey proteins are of considerable interest for the production of functional products or products with prophylactic properties. The creation of such products includes the obtaining of bioactive peptides of define biological action. Taking into account the specifics of their placement in the primary structure, it is advisable to use homogeneous protein precursors from milk whey to obtain them. One of the methods for one-stage separation of whey proteins is disc-electrophoresis in the native PAGE system for alkaline and neutral proteins. The purpose of this work was to determine the parameters of the preparative variant of disc-electrophoresis for the selection of homogeneous whey proteins. The research was performed on a modified apparatus of Stadier type. Proteins of milk whey were isolated by the precipitation of caseins at an isoelectric point. The precipitate of caseins was separated by centrifugation. Homogenous $\alpha$-lactalbumin $(\alpha-L A)$ and $\beta$-lactoglobulin $(\beta-L G)$ fractions were used to identify milk whey proteins, which were obtained by double gel-filtration on Sephadex G-100 (fine). Homogeneity and fractional composition of milk serum proteins were determined by analytical disc-electrophoresis in plates of polyacrylamide gel. The concentration of proteins in the samples was determined spectrophotometrically (spectrophotometer SF-46) at a wavelength $\lambda=280 \mathrm{~nm}$.

The obtained results prove the feasibility of using PAGE plates for the preparative fractionation of serum milk proteins. The allowable duration and conditions for identification of protein fractions are established. It was shown that the yield of proteins in the composition of homogeneous fractions was $69.2 \%$. In this case, the correlation between the number of obtained fractions ( $\beta$-LG, $\alpha$ $L A, B S A$ and $I G)$ is close to their distribution in milk serum.
\end{abstract}

Key words: Serum proteins of milk, separation of fractions, preparative electrophoresis.

\section{Вступ}

Протеїни сироватки молока виконують низку важливих біологічних функцій. Це в першу чергу забезпечення організму у постнатальний період амінокислотами, а також транспортування жирних кислот, ретинолу, участь у синтезі лактози у молочній залозі, транспортування іонів кальцію, імунний захист, антимікробна та антиоксидантна дія (Fox et al, 2015). B останні десятиліття було відкрито більше сотні біоактивних пептидів, які можуть утворюватись в результаті протеолітичного розщеплення протеїнів сироватки молока (Park, 2009). Ці пептиди також здатні впливати на функції фізіологічних систем організму. За видами біологічної дії серед них знайдено інгібітори ангіотензин-перетворювального ензиму, пептиди 3 опіоїдною та бактерицидною дією, іміномодуляторні та гіпохолестеролемічні пептиди, а також пептиди, що впливають на моторику кишечника. Такі пептиди становлять значний інтерес як природні інгредієнти для створення функціональних харчових продуктів або продуктів 3 профілактичними властивостями. Створення таких продуктів пов'язане 3 необхідністю виробництва біоактивних пептидів з певною біологічною дією. У зв'язку з цим, необхідно враховувати певну специфіку розміщення біоактивних пептидів у первинній структурі протеїнів-попередників з сироватки молока (Yukalo et al, 2009). Тому для отримання функціональних пептидних інгредієнтів певної біологічної дії доцільним $є$ використання окремих гомогенних протеїнів. На сьогоднішній день доступні і ефективні методи отримання протеїнів-попередників 
з сироватки молока у промислових масштабах відсутні. Існуючі є або складними, багатостадійними і дорогими або в іншому випадку не можуть забезпечити достатньо високий ступінь гомогенності протеїнових фракцій.

Одним з методів, який міг би забезпечити ефективне одностадійне розділення протеїнів сироватки молока, є електрофорез. Раніше в нашій лабораторії було встановлено, що найбільш оптимальною для цього є анодна система диск-електрофорезу в нативних умовах. Для іiі успішного використання необхідно провести дослідження впливу параметрів електрофоретичної системи на ефективність препаративного розділення протеїнів сироватки молока (Yukalo, 2014).

Мета роботи. Встановлення параметрів проведення препаративного диск-електрофорезу протеїнів для виділення гомогенних протеїнів сироватки молока

\section{Матеріал і методи досліджень}

В роботі було використано свіже молоко кислотністю 17-19 ${ }^{\circ}$ Т. Молоко знежирювали центрифугуванням на центрифузі ОПН-8 (5000 об/хв. протягом 15 хвилин). Протеїни сироватки молока виділяли осадженням казеїнів в ізоелектричній точці. Осад казеїнів відділяли центрифугуванням (3000 об/хв. протягом 10 хв). Процедуру повторювали двічі. Протеїни сироватки молока очищали від низькомолекулярних компонентів гель-фільтрацією на колонці з сефадексом G-25 (medium) зрівноваженим відповідним електрофоретичним буфером.

Для ідентифікації протеїнів сироватки молока використовували гомогенні фракції $\alpha$-лактальбуміну ( $\alpha$ LA) i $\beta$-лактоглобуліну ( $\beta$-LG), які отримували шляхом повторної гель-фільтрації на сефадексі G-100 (fine).

Гомогенність і фракційний склад протеїнів сироватки молока визначали аналітичним дискелектрофорезом у пластинах поліакриламідного гелю (ПААГ) (Yukalo, 2014). Електрофореграми фарбували $7 \%$ оцтовою кислотою. Для фарбування використовували барвники: кумасі голубий (аналітичний варіант електрофорезу) і амідочорний 10В (препаративний варіант електрофорезу). Кількісну обробку електрофореграм проводили денситометрією з використанням функції зчитування графічних зображень imread (Yukalo et al, 2007).

Концентрацію протеїнів у зразках визначали спектрофотометрично (спектрофотометр СФ-46) при довжині хвилі $\lambda=280$ нм. При цьому використовували коефіцієнт поглинання $\left(D_{1 c u}^{1 \%}\right)$ для протеїнів сироватки молока - 12,3. Для приготування буферних розчинів, а також проведення хроматографічних і електрофоретичних досліджень використовували реактиви фірми «Reanal» (Угорщина), «Sigma» (США), «Pharmacia» (Швеція), а також реактиви вітчизняного виробництва

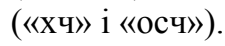

Математично-статистичний аналіз виходу протеїнових фракцій проводили з використанням програми Microsoft Office Excel 2003.

\section{Результати та їх обговорення}

Для проведення аналітичного електрофорезу протеїнів молока використовують системи однорідного або диск-електрофорезу. Раніше нами було встановлено, що для препаративного розділення цих протеїнів найбільш ефективним є диск-електрофорез в нативній системі ПААГ для лужних і нейтральних протеїнів (Yukalo et al, 2009). Його можна проводити в пластинках або стовпчиках ПААГ. На рис. 1 показані результати аналітичного диск-електрофорезу протеїнів сироватки молока отримані цими двома способами. Як видно на електрофореграмах така система дозволяє ефективно розділити і ідентифікувати такі важливі фракції, як $\beta$-LG , $\alpha$-LA, протеозо-пептонну фракцію (PPF) і імуноглобуліни (Ig). Необхідно відзначити, що електрофорез у стовпчиках ПААГ дозволяє більш чітко розділити $\beta-\mathrm{LG}$ на дві фракції А і В (рис. 1(2)). Проте для препаративного виділення більш зручним $\epsilon$ електрофорез у пластинах ПААГ. Особливо це стосується стадії ідентифікації фракцій і їх екстракції. Тому за основу для препаративного варіанту було взято електрофорез у пластинках ПААГ. Відпрацювання процесів виділення протеїнів сироватки проводили в апараті типу Стадієра (Osterman, 1981).

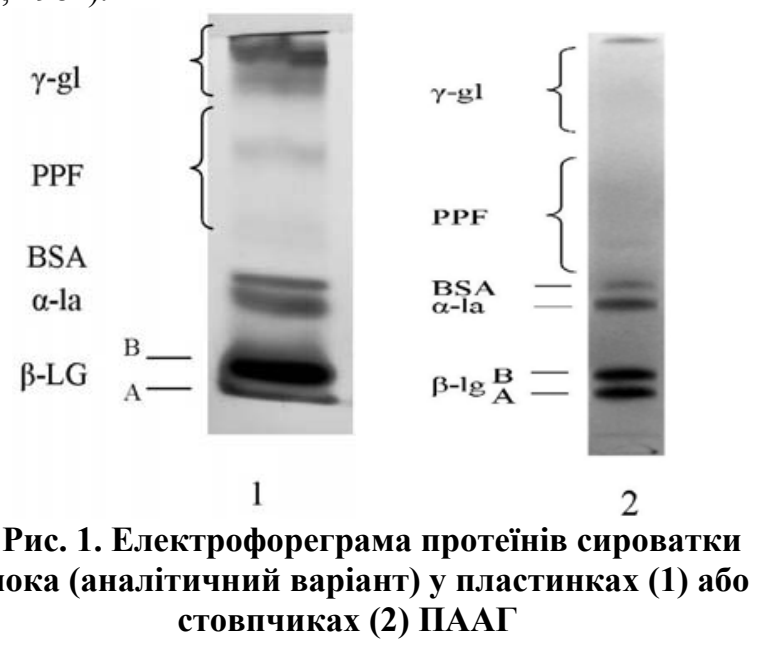

Перш за все нами було встановлено допустиму тривалість дифузного розмивання протеїнових смужок у ПААГ до їх фіксації. Це необхідно для того, щоб провести ідентифікацію протеїнових фракцій. Вона складається 3 таких тривалих операцій як фарбування крайніх полосок гелю і їх інтенсивне відмивання. Все це становить від 30 до 60 хвилин. Необхідно відзначити, що для ідентифікації протеїнових фракцій у даному випадку можна використовувати не лише кумасі голубий, але і амідошварц 10 В. Враховуючи велику концентрацію протеїну, ефективність амідошварцу 10 В достатня для надійної ідентифікації фракцій. В цей же час полоска ПААГ забарвлена ним швидше відмивається. Для встановлення допустимої тривалості дифузного розмивання протеїнових смужок нами було проведено візуалізацію пластинок ПААГ після препаративного диск-електрофорезу через різні проміжки часу (до 2 годин) без фіксації 
протеїнів. На рис. 2 показано пластинку ПААГ після двох годин експозиції без фіксації. Отримані результати свідчать про те, що за такий період в гелі не відбувається помітного розмивання протеїнових фракцій.

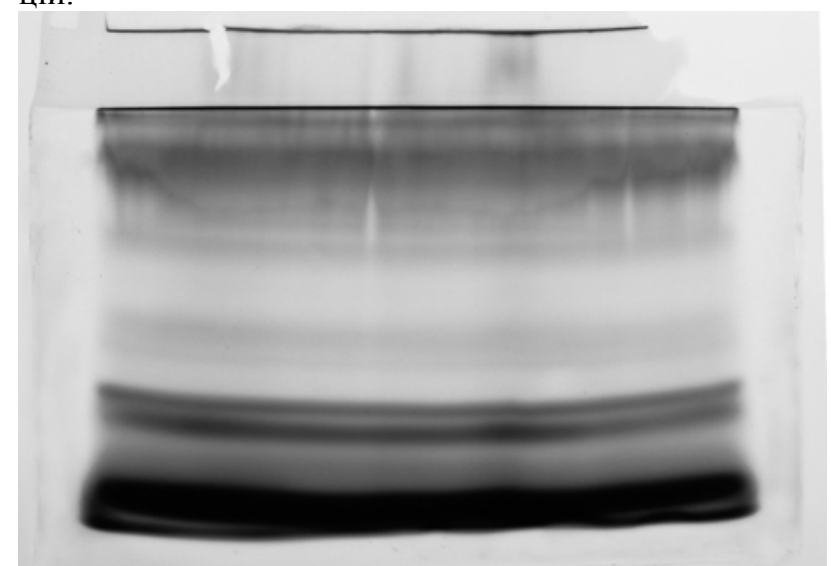

Рис. 2. Вигляд пластинки ПААГ 3 протеїнами сироватки молока (препаративний диск-електрофорез) після двох годин витримки без фіксації
Для проведення препаративного електрофорезу протеїнів сироватки молока нами було збільшено об'єм електрофоретичної камери типового апарату Стадієра, що дозволило в 7-9 разів збільшити кількість протеїну у взірці для фракціонування. Для перевірки, як такі зміни можуть вплинути на ефективність розділення, було проведено чотири препаративні електрофорези. Одну пластинку зафіксували і зафарбували для оцінки ефективності розділення з допомогою денситометрії. Три інші пластинки використали для екстракції і оцінки виходу загального протеїну і його фракцій. Зафіксовану пластинку ПААГ після препаративного електрофорезу і іï денситограму показано на рис. 3.

Оцінка виходу загального протеїну сироватки молока і окремих його фракцій представлена в таблиці 1. Отримані результати свідчать, що збільшення кількості протеїну у взірці взятому для фракціонування у модифікованому апараті призводить до незначного зменшення виходу загального протеїну після екстракціï.

1
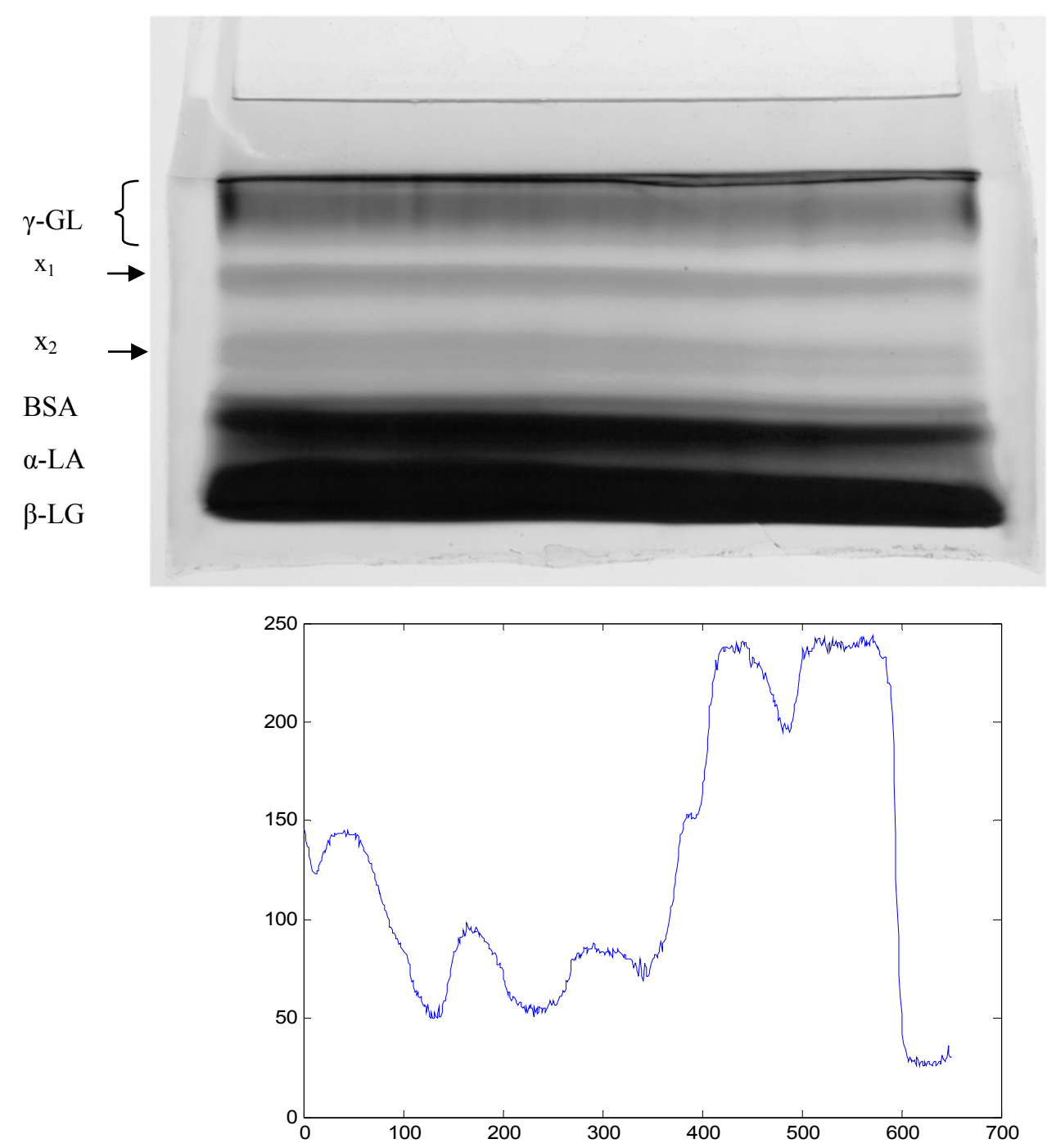

Рис. 3. Електрофореграма (1) і денситограма (2) протеїнів сироватки молока після зміни розмірів електрофоретичної камери для препаративного диск-електрофорезу 
Табличя 1

Вихід протеїнів сироватки молока за результатами трьох препаративних електрофорезів

\begin{tabular}{|c|c|c|c|c|c|}
\hline \multirow{2}{*}{$\begin{array}{c}\text { Етап визначення виходу } \\
\text { протеїнів після елект- } \\
\text { рофорезу }\end{array}$} & \multicolumn{3}{|c|}{ Кількість екстрагованих протеїнів кожної фракції (мг) за резуль- } \\
\cline { 2 - 6 } \\
\cline { 2 - 6 } татами трьох електрофорезів
\end{tabular}

* В кожному екстракті і у взірцях для фракціонування

Цей вихід за результатами трьох електрофорезів становить 69,2\%. До модифікації він становив більше 70\%. Співвідношення між кількістю отриманих фракцій ( $\beta$-LG, $\alpha$-LA, BSA і IG) відповідає їх нормальному розподілу у сироватці молока.

\section{Висновки}

Отримані результати доводять доцільність використання пластинок ПААГ для препаративного фракціонування протеїнів сироватки молока. При цьому дифузія протеїнових фракцій в гелі несуттєво впливає на ефективність розділення при витримуванні гелю без фіксації до 2 годин, що цілком достатньо для ідентифікації фракцій. Вихід протеїнів при модифікації електрофоретичної камери апарату Стадієра і збільшенні кількості взірця (в 7-9 разів) за результатами трьох електрофорезів становить 69,2\%. До модифікації він досягав більше $70 \%$.

\section{Бібліографічні посилання}

Fox, P., Uniacke-Lowe, T., McSweeney, P., O’Mahony, J. (2015). Dairy Chemistry and Biochemistry.

Park, Y.W. (2009). Bioactive components in milk and dairy products. Wiley - Blackwell.
Yukalo, A.V., Datsyshyn, K.Ye., Yukalo V.G. (2013). Bioaktyvni peptydy proteiniv syrovatky moloka koriv (Bos taurus). Biotekhnolohiia Akta. 6, 49-61 (in Ukrainian).

Yukalo, A., Yukalo, V., Shynkaryk, M. (2009). Electrophoresis separation of the Milk Protein. Proceedings of the International Conference on Bio and Food Electrotechnologies, 227-231.

Yukalo, A.V. (2014). New approach for isolation of individual caseins from cow milk by the preparative electrophoresis. Advances in Biological Chemistry. 4(6), 382-387.

Yukalo, V. G., Yavorskyy, B.I., Storozh, L.A., Solovodzinska, I.Y. (2007). Kilkisnyi elektroforetychnyi analiz bilkiv kazeinovoho kompleksu . Biolohiia tvaryn. 9(1-2), 295-298 (in Ukrainian).

Osterman, L.A. (1981). Metody issledovaniya belkov i nukleinovykh kislot: Elektroforez i ultratsentrifugirovaniye (prakticheskoye posobiye). M.: Nauka (in Russian). 